\title{
Sivistyksen keitaasta formulatalliksi?
}

\section{Kansalaisopiston henkilökunnan kokemuksia markkinaperusteisesta aikuiskoulutuspolitiikasta}

\author{
EMILIA VALKONEN \& JUHAKAUPPILA
}

\begin{abstract}
Artikkeli kuvaa kansalaisopiston henkilökunnan kokemuksia opiston muuttumisesta sivistyksen keitaasta markkinavetoiseksi oppilaitokseksi. Vapaaseen sivistystyöhön kiinteästi liittyvän sivistysperinteen ja koulutuksen välineellisyyttä, tehokkuutta ja kaupallisuutta korostan aikuiskoulutuspolitiikan välillä on ristiriita. Kirjoittajat eivät kuitenkaan pidä markkinaperusteisuutta yksinomaan kielteisenä ilmiönä, vaikka se onkin tuonut perustavanlaatuisia muutoksia kansalaisopiston työhön.
\end{abstract}

Yleissivistävä koulutus on perinteisesti rahoitettu Suomessa julkisin varoin. Julkinen rahoitus on turvannut opintojen saatavuuden, muodostamalla perustan kattavan oppilaitosverkoston rakentamiselle ja opintojen maksuttomuudelle. Siirtyminen sivistyksen merkitystä korostavasta suunnittelukeskeisestä aikuiskoulutuspolitiikasta 1980luvun puolivälistä lähtien markkinaperusteiseen heijastui käytäntöön uusliberalismin hengessä toteutettuina tehostamistoimina, joiden kautta koulutuksen kentälle esiteltiin yritysmaailman ajatuksia ja markkinaperiaatteita (viite 1). Koulutuksen yhteiskunnalliset tehtävät siirtyivät samalla aiempaa voimakkaammin tasa-arvoisuuden ja oikeudenmukaisuuden tavoittelusta valtion taloudellisen kilpailukyvyn edistämiseen, mikä on herättänyt kysymyksiä Suomen asemasta hyvinvointivaltiona. (Alanen 1992, 11-15; Antikainen 2006, 238; Ball 2007, 25; Kantola 2006, 173.)

Suomalainen aikuiskoulutuspolitiikka näyttäytyy mielenkiintoisessa valossa globaalin talouskriisin jälkeisissä olosuhteissa, jossa se pyrkii toimillaan omaksumaan yhä vahvemmin EU:n koulutuspolitiikan ja amerikkalaisen talousjärjestelmän piirteitä. Samaan aikaan amerikkalainen järjestelmä näkee Nobelin palkinnon saaneen taloustieteilijä Paul Krugmanin johdolla pohjoismaisen hy- vinvointivaltion, verovaroin kustannettavan terveydenhoidon ja koulutusjärjestelmän amerikkalaisten tulevaisuuden mallina. Onkin syytä kysyä, tulisiko suomalaisen aikuiskoulutuspolitiikan ja kansalaisopistotoiminnan marssia yhä nopeammin markkinoiden tahdissa vai ottaa askelia takaisin kohti hyvinvointivaltion aikaista sivistyksellisen tasa-arvon politiikkaa?

\section{Aineisto ja analyysi}

Tarkastelun kohteena olevan alueellisen kansalaisopiston voi katsoa edustavan markkinaperusteisuuden osalta tyypillistä nykypäivän kansalaisopistoa opintojen maksullisuuden ja opistojen yhdistymisprosessin läpikäymisen suhteen (viite 2). Pitkän työkokemuksen omaavan kansalaisopiston henkilöstön kokemukset kuvaavat perinteisen opistotoiminnan ja markkinaperusteisen aikuiskoulutuspolitiikan jännitettä paikallisena ilmiönä.

Aineisto kerättiin alkuvuodesta 2008 teemahaastatteluilla, joissa selvitettiin opiston henkilökunnan kokemuksia opiston tehtävien, arvojen, hallinnon, rahoituksen ja opistotyön muutoksista (vrt. Sihvonen 1996) (viite 3). Haastatteluihin osallistui 11 opiston henkilökunnan jäsentä, joiden opistotyökokemus vaihteli 7-38 vuoden välillä. 


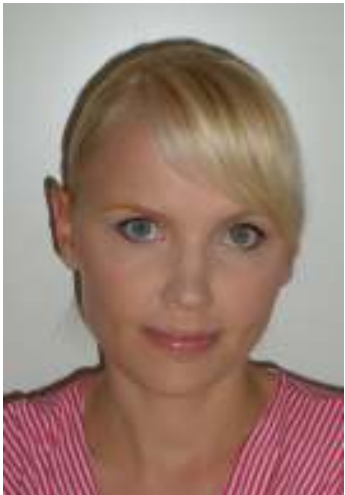

Emilia Valkonen

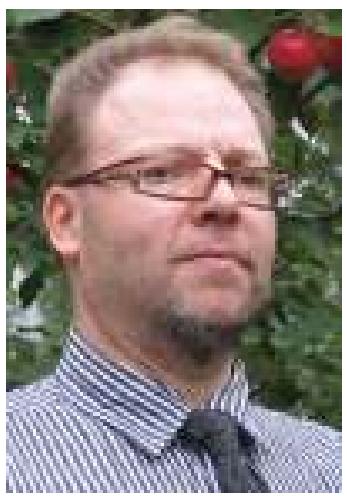

Juha Kauppila
Valtaosalla haastatteluun osallistuneista oli pitkä, noin 30 vuoden opistotyökokemus. Opiston henkilökunnan kirjo oli aineistossa hyvin edustettuna. Mukana oli henkilöitä ammattinimikkeillä rehtori, apulaisrehtori, opettaja, suunnittelijaopettaja ja tuntiopettaja. Haastattelut kestivät pääasiassa noin puolitoista tuntia.

Analysoimme artikkelissa kahta kysymystä: 1) Millaisena opiston henkilökunta kokee aikuiskoulutuspoliittisen muutoksen merkityksen opistotoiminnassa? 2) Millainen merkitys muutoksella on ollut henkilöstön ammatillisille identiteeteille? Aineiston analyysi rakentui aineistolähtöisen teemoittelun pohjalle. Analyysi muodosti hermeneuttisen kehän kaltaisen prosessin, jossa ymmärrystä rakennettiin aineiston toistuvan kriittisen tarkastelun kautta. Kriittisyyttä ylläpidettiin mm. kokoamalla opiston henkilökunnan kokemukset matriisiksi, jonka avulla jäsennettiin haastateltavien eri teemoille antamia merkityksiä.

Kuvaamme seuraavassa markkinaperusteisuuden opistotoimintaan tuomaa muutosta, opiston henkilökunnan keskeisimpien kokemusten kautta. Ensimmäisen ja toisen teemaluvun painopisteenä ovat toiminnan rakenteellisiin muutoksiin ja politiikkaan liittyvät kokemukset. Kolmannessa teemaluvussa tarkastellaan rakenteellisten muutosten opiston henkilökunnan identiteetteihin luomia merkityksiä. Artikkelin lopussa keskustelemme analyysin tuottamista havainnoista ja niiden merkityksistä sekä luomme katsauksen markkinaperusteisen kansalaisopistotoiminnan tulevaisuuteen.

\section{Kunnallisen päätösvallan kasvun merkitys}

Markkinaperusteisuuden voi katsoa rantautuneen kansalaisopistotoimintaan 1990-luvun alkuvuosina, valtionosuusjärjestelmään kohdistuneiden uudistusten myötä. Opistotoimintaan korvamer- kityistä, menoperusteisesti myönnetyistä valtionosuuksista siirryttiin tällöin suoriteperusteisesti määräytyvään opetus- ja kulttuuritoimen könttäsummabudjettiin. Uudistus antoi kunnalle vallan päättää opiston saaman taloudellisen tuen määrästä. (Sihvonen 1996, 156.) Kunnan taloudellisen päätösvallan voimistuminen ilmentää päätös- ja toimivallan hajauttamista alueelliselle tasolle. Hajauttamistoimien avulla kevennettiin julkisen hallinnon ohjausta ja byrokraattisuutta. (ks. Rinne, Kivirauma \& Simola 2002, 652-653.)

Hajauttamistoimien ja valtionosuusuudistusten kautta tavoiteltu vapaus näyttäytyy opiston henkilökunnan kokemusten perusteella näennäisenä, sillä kunnan myöntämien resurssien määrä ohjaa opiston käytännön toimintaa voimakkaasti. Opistotoiminta näyttää siten jääneen kuntien armoille.

"Me olemme täysin riippuvaisia meidän omistajayhteisöstä, että ei siinä nyt ole mitään kysymystäkään, että toimitaan kuten yhteisö määrää ja päättäjät määräävät." Pekka, työkokemus 30 vuotta

Kunnan voimistuneen taloudellisen päätäntävallan myötä opisto on kohdannut toistuvia resurssileikkauksia, joiden seurauksena opiston on täytynyt nostaa osallistujilta kerättäviä maksuja yhä uudelleen ja uudelleen, ylläpitääkseen toimintaansa. Markkinaperusteisuuden opintomaksuihin tuomaa muutosta ilmentävät opiston henkilökunnan kuvaukset maksuista markka-aikana ja nykyisin korkeimmillaan.

"Silloin kun minä menin 78, 79 niin opistossa opintomaksu oli kolme markkaa vuosi, jolla sai käydä opiskelemassa niin paljon kuin halusi. " Martti, työkokemus 30 vuotta

"113 euroa yksi kurssi.Onhan se monin kymmenkertaistunut... yksi kurssi.." Veikko, työkokemus 38 vuotta

Maksujen korotuspaineet näyttävät voimistuneen erityisesti 2000-luvulla, opistojen yhdistymisen jälkeen. Opintomaksujen nykyistä tasoa pidetään opistossa liian korkeana, mutta toisaalta maksut voi nähdä edelleen alhaisia verrattuna yksityisten palveluiden hintoihin (vrt. Tuomisto 1998, 271).

Opintomaksujen toistuvat, lamavuosista käynnistyneet korotukset ilmentävät osaltaan opiston 
itsenäisen, aktiivisen rahanhakutoiminnan merkityksen korostumista. Opintomaksujen ohella itsenäistä rahanhakutoimintaa harjoitetaan järjestämällä aiempaa enemmän maksupalvelu- ja myyntikoulutusta sekä hakemalla projektirahoituksia (vrt. Sihvonen 1996, 134-136).

Itsenäinen rahanhakutoiminta ei näytä tuoneen helpotusta opiston taloudelliseen ahdinkoon, vaan säästöpaineet ovat ajaneet opiston myös leikkaamaan toistuvasti opetustuntien määrää. Aineistosta käy ilmi, ettei tuntimäärien kaventaminen kohdistu alueellisessa opistossa yhtä suurena kaikille ainealueille, vaan toisiin aineisiin panostetaan tuntiresursseja selvästi muita enemmän.

"Tunteja joudutaan aika paljon supistamaan. Minun ainealuetta rankaistiin tässä tänä vuonna eniten, että muilta otettiin kaksi sataa tuntia niin minulta otettiin kolmesataa tuntia." Esko, työkokemus 33 vuotta

Tuntiresurssien määrän voi osaltaan katsoa kuvaavan ainealueen menestyksellisyyttä ja sitä kautta sen opistossa nauttimaa arvostusta. Menestymisen ohjatessa tuntiresurssien määrää, kohdistetaan ainealueeseen sitä enemmän resursseja, mitä enemmän ainealueelle on kysyntää ja kursseille tulijoita (vrt. Ball 2003).

Toiminnan arvon määräytyminen menestymisen ja tuloksellisuuden perusteella ei liity yksin ainealueiden toimintaan. Koko opistotoiminnan arvo näyttää markkinaperusteisen politiikan myötä määrittyvän aiempaa voimakkaammin koulutusmarkkinoilla menestymisen kautta (vrt. TuomolaKarp 2005, 161; Rinne \& Vanttaja 1999, 131). Arvostuksen ja julkisen rahoituksen saamisen ehtona voi nähdä toiminnan tarpeellisuuden ja menestyksellisyyden osoittamisen suhteessa muihin alueella toimiviin koulutusorganisaatioihin. Harrastuspohjaisen kansalaisopistotoiminnan on haasteellista osoittaa tarpeellisuutensa alueen koulutusmarkkinoilla, kun se joutuu kamppailemaan asemastaan ja rahoituksesta mm. perus- ja lukiokoulutuksen rinnalla. Lisäksi opiston menestymistä alueen koulutusmarkkinoilla vaikeuttaa se, että vallitsevan (aikuis)koulutuspolitiikan aikana arvostetaan koulutuksen välineellisyyttä ja koulutuksesta saatavia yhteiskunnallisia tuottoja.

Julkisen rahoituksen toistuvat leikkaukset heijastuvatkin opistotyön käytäntöön kokemuksina toiminnan saaman arvostuksen heikkenemisestä. Arvostuksen heikkenemisen taustalla nähdään erityisesti opistotoiminnasta saatavien konkreettisten hyötyjen mittaamiseen ja osoittamiseen liittyvät ongelmat (vrt. Sihvonen 1996, 228, 231).

"Ainakin meidän piireissä ja jotka tuntevat opistotoimintaa, niin yleinen vahva käsitys on, että yhteiskunta ja nämä kunnan päättäjät, niin he eivät osaa antaa sellaista arvoa tälle kuin mitä merkityksiä ja vaikutuksia tosiasiassa on. Että hirveän vaikea on alkaa mittailemaan, että vaikka liikuntaryhmässä kun kävit, että miten se hyvinvointi on siitä johtuen kasvanut, että siirtyy tämä vuodeosastolle meno." Olavi, työkokemus 29 vuotta

Kansalaisopiston markkinoilla menestymistä voi osaltaan vaikeuttaa opiston laaja-alainen opintotarjonta, minkä vuoksi opistolle ei muotoudu selväalaista profiilia tai roolia alueen koulutusmarkkinoilla.

"\{...\} Me ei olla osattu profiloitua riittävän terävästi tässä kaupungissa. Me ollaan vähän nössöjä.” Tuija, työkokemus 27 vuotta

Opiston selkeän roolin puuttumisen voi nähdä julkisen rahoituksen ja arvostuksen heikkenemisen taustalla (vrt. Jokinen 2002, 221). Toisaalta selkeän roolin tai profiilin rakentaminen on opistolle haasteellista, kun sen toiminta on perinteisesti ymmärretty laaja-alaisena, alueen tarpeisiin vastaavana. Profiloituminen markkinoilla menestymisen ehtona nousee siten ristiriitaan opistotoiminnan perinteisen, laaja-alaisen roolin säilyttämisen kanssa.

\section{Asiakaslähtöisyyden ja kilpailun voimistuminen}

Kansalaisopisto on perinteisesti tarjonnut paikalliseen sivistystarpeeseen vastaavia opintoja (ks. Alanen 1988, 15). Markkinaperusteisen politiikan aikana toteutuneiden toistuvien resurssileikkausten vuoksi opiston on aineiston perusteella täytynyt omaksua aiempaa voimakkaammin asiakaslähtöinen, kysyntään perustuva toimintatapa (vrt. Sihvonen 2004, 117). Opistolla itsellään ei enää juuri olekaan ohjaavaa asemaa tarjonnan määrittäjänä ja opiston oma, yhteisöä ja yhteiskuntaa ohjaava rooli on heikentynyt.

”Katsotaan herkästi kysyntää ja yritetään vas- 
tata siihen, mutta siinä on sitten se vaara tavallaan, että me ei olla millään tavalla semmoisessa ohjaavassa roolissa meidän kulttuurissa. Että meidän panos tavallaan siinä häviää merkityksettömäksi, koska me ei olla siellä takana ajattelemassa, että hei tämmöiset asiat yhteiskunnassa on tärkeitä tai yhteisössä." Esko, työkokemus 33 vuotta

Kysyntälähtöisyyden korostumisen myötä vähäiset resurssit pyritään käyttämään mahdollisimman joustavasti ja tehokkaasti, tuhlaamatta niitä osallistujamääriltään epävarmojen kurssien järjestämiseen.

"Kyllä se aika pieni osa semmoista, että kokeillaan kepillä jäätä...että katsotaan tuleeko yhtään, että kyllä se on hirveän tärkeä se kysynnän arviointi." Olavi, työkokemus 29 vuotta

Kysyntään perustuvan toimintatavan korostuminen on luonnollisesti voimistanut kysynnän arvioinnin ja ennakoinnin merkitystä opistossa. Nopeasti muuttuvien trendien seuraaminen ja ajan hengessä pysyminen ovat nousseet kysynnän ennakoinnin ja opintotarjonnan suunnittelun keskeisiksi osa-alueiksi. Kysynnän arviointi ja ennakointi koetaan opistossa kuitenkin haasteelliseksi, eikä siihen näytä olevan riittäviä välineitä.

Julkisten resurssien vähäisyyden ohella asiakaslähtöisen toimintatavan voimistumista on tukenut opiston kohtaama kilpailu. Aineiston perusteella kilpailu on alueellisessa opistossa osin korvannut suunnittelukeskeisellä aikuiskoulutuspolitiikan kaudella harjoitetun samankaltaisten palveluntarjoajien keskinäisen yhteistyön (vrt. Tuomisto 1998; Rinne \& Vanttaja 1999, 130).

"Siellä meidän oli pakko tehdä yhteistyötä. Olihan sielläkin toimijoita, urheiluseuroja ja muita, mutta siellä tehtiin selkeämpi työnjako. Eihän siinä mitään järkeä olisi ollut ryhtyä tappelemaan samoista ihmisistä. Jaettiin reviirit." Martti, työkokemus 30 vuotta.

$"\{$...\}luet jonkin kurssin nimen lehdestä, niin täällähän joistakin löytyy seitsemän, kahdeksan eri mahdollista järjestäjää samalle kurssille, että siinä mielessä tilanne on kyllä muuttunut hyvin paljon." Veikko, työkokemus 38 vuotta
Opistotoiminnan kilpailijoiksi ovat nousseet paitsi alueella toimivat koulutusorganisaatiot, myös muut oppimismahdollisuuksia ja harrastustoimintaa tarjoavat tahot. Opiston voi siten katsoa kilpailevan ihmisten vapaa-ajasta laaja-alaisilla oppimis- ja koulutusmarkkinoilla (vrt. Jarvis 1996).

Kilpailu ei näytä kohdistuvan yhtä voimakkaana kaikille ainealueille. Tästä huolimatta se on synnyttänyt tarpeen osallistujien aktivoimiseen ja opiston markkinoinnin kehittämiseen. Markkinoinnin kehittäminen näyttäytyy tärkeänä erityisesti niille ainealueille, joihin kohdistuu kysyntää muita vähemmän, sillä osallistumisaktiivisuus on aineiston perusteella jakautunut kahtia ainealueiden välillä. Markkinointiin panostaminen on noussut tärkeäksi myös alueellisen opiston perustamisen myötä laajentuneen toimialueen vuoksi.

Opistojen yhdistymisen vuoksi laajentunut toimialue ja aiempaa suuremmat etäisyydet ovat opintomaksujen toistuvien korotusten ohella rajoittaneet osallistumista sekä opintojen saatavuutta (vrt. Rinne \& Vanttaja 1999, 131; Vaherva ym. 2006, 52). Opintojen saatavuuden ja sivistyksellisen tasa-arvon uhkaksi on aineiston perusteella noussut, kysyntälähtöisen toimintatavan korostumisen seurauksena, opintojen kohdentaminen maksukykyisten asiakkaiden tarpeiden ja toiveiden mukaan. Tällöin vaarana on suppealle ryhmälle kohdistettujen kapea-alaisten erikoiskurssien tarjonnan voimakas kasvaminen, mikä irtaannuttaa opiston vapaan sivistystyön perinteisestä sivistystehtävästä. (vrt. Sihvonen 2004, 117.)

Kysyntälähtöisen toimintatavan korostuminen ja korkeat opintomaksut näyttävät murentaneen opistotoiminnan perinteitä. Toisaalta ne ovat nostaneet toiminnan laadukkuuden ylläpitämisen ja kehittämisen uuteen arvoon opiston sisällä, asiakkaiden kasvaneen palautteenantoaktiivisuuden ja vaatimustason myötä (vrt. Sihvonen 1989, 7071; Tuomola-Karp 2005, 212).

"Työnteko muuttui käytännössä, kun nämä opiskelijat ryhtyivät maksamaan, joutuivat maksamaan opintomaksuja, niin silloinhan se tuli esimerkiksi se...en minä usko, että me huonosti opetettiin sitä ennenkään, mutta nyt tuli sille opetuksen laadulle erillinen painoarvo, koska ihminenhän lähtee pois... meidän on opetettava sen verran hyvin, että ihmiset suostuvat maksamaan ja vielä viihtyvät siellä kurssilla” Tuija, työkokemus 27 vuotta 
Toiminnan ja sen laadun kehittämisen kautta voidaan parantaa opiston ja ainealueiden taloudellista suorituskyvykkyyttä, vastaamalla asiakkaiden vaatimuksiin aiempaa paremmin (vrt. Tuomola-Karp 2005). Toiminnan laadukkuuden voi näin ollen ymmärtää keskeisenä kilpailun välineenä (vrt. Tuomisto 1998, 277-278), ja siten toiminnan jatkuvuuden ehtona. Laadukkuuden ja kysyntälähtöisen toimintatavan korostunut merkitys onkin aineiston perusteella synnyttänyt opistossa paineen kattavan arviointi- ja palautejärjestelmän kehittämiseen.

Opiston tiukkojen taloudellisten reunaehtojen vuoksi laadukkuuden ylläpitämiseen ja kehittämiseen suunnatut resurssit ovat rajalliset. Kaikilla ainealueilla ei opiston henkilökunnan kokemusten perusteella näytäkään olevan yhtäläisiä mahdollisuuksia toiminnan kehittämiseen, sillä tuloksellisuus ohjaa myös kehittämisresurssien jakoa.

"Olen saanut semmoisia vastauksia, että tuntuu, että mitä turhaan natisee ja varsinkin kun, jos ei ole väkeä hirveästi tulossa, niin mitä niitä välineitäkään ostelemaan.” Leena, työkokemus 29 vuotta

Heikko menestys ainealueiden välisessä resurssijaossa voi synnyttää negatiivisen kierteen, jossa vähäiset resurssit eivät mahdollista toiminnan kehittämistä tai edes ajassa mukana pysymistä. Tämän vuoksi kysyntä voi heikentyä ja mahdollisuudet tulevien resurssien saamiseen kaventuvat. Kysyntälähtöisyyden korostumisen varjopuolena voi siten nähdä muita heikommin menestyvien ainealueiden supistumisen entisestään, jos resurssit suunnataan toistuvasti pääosin menestyville, kysytyille aineille, eikä muilla ainealueilla ole riittäviä resursseja toimintansa kehittämiseen.

\section{Opiston henkilökunnan ammatillisten identiteettien kriisi}

Kansalaisopistojen opetus toteutettiin pitkään sivutoimena opetustyötä tekevien tuntiopettajien voimin. Päätoimisten opettajien määrä kasvoi opistoissa vähitellen suunnittelukeskeisellä politiikan kaudella. (ks. Alanen 1992, 47.) Aineiston valossa päätoimisten opettajien ammatillisen identiteetin voi nähdä säilyneen perinteisenä opettajuutena aina 2000-luvulle, opistojen yhdistymiseen saakka. Tällöin markkinaperusteisuuden tehostamispyrkimykset näyttävät kohdistuneen opiston opet- tajistoon ja suuri osa entisistä päätoimisista opettajista siirtyi suunnittelijaopettajan tehtäviin. Siirtyminen päätoimisesta opettajuudesta suunnittelijaopettajuuteen merkitsi käytännössä työtehtävien monipuolistumista, mutta ennen kaikkea työn painopisteen siirtymistä pääasiallisesta opetustyöstä hallinnollisiin tehtäviin ja opetuksen suunnitteluun sekä kehittämiseen. (vrt. Jokinen 2002, 266.)

"Aikaisemmin oli aina päätoimisia opettajia, joilla oli tietty opetusvelvollisuus plus muun työn velvollisuus, mutta he olivat selkeästi opettajia, että heillä oli paljon opetustunteja. Se muu työ oli pieni ja rajallinen joka sitten jäi suunnitteluun." Matti, työkokemus 8 vuotta

"Se muuttui oleellisesti sillä tavalla, että se muuttui enemmän hallinnolliseksi. Että sitten kuitenkin se, että semmoinen tuntuma opetukseen on, että minä opetan yhtenä päivänä viikossa. \{...\} silloin minä tein 570 tuntia opetusta ja 212 tuntia muuta työtä, nyt minä teen tuhat tuntia muuta työtä ja kaksi sataa tuntia opetusta." Esko, työkokemus 33 vuotta

Opetustyön vähentyminen ei näytä liittyvän yksin suunnittelijaopettajien työhön, sillä aineiston pohjalta voi todeta, että myös edelleen päätoimisesti opetustyötä tekevien opettajien työ on muuttunut aiempaa hallinnollisemmaksi. Päätoimisten opettajien ja suunnittelijaopettajien opetustyön määrän vähentyessä, on opetus toteutettu yhä vahvemmin tuntiopettajien voimin.

Tuntiopettajien määrällisen kasvun ja vakinaisen työvoiman vähentymisen (Jokinen 2002, 4647; Yrjölä 1996, 130) voi katsoa kuvaavan opistotoiminnan siirtymistä joustavaan tietotyöhön, jossa vakinaisen työvoiman vähäistä määrää kompensoidaan tuntiopettajilla. Informationaalisen ajan työhön liittyvänä piirteenä voi nähdä työvoiman jakaantumisen ydintyövoimaan ja korvattavaan työvoimaan. Koska korvattavan työvoiman määrää voidaan säädellä tarpeiden ja markkinatilanteen mukaan, kuuluu epävarmuus korvattavan työvoiman arkeen. (Castells 1996, 201-279; Siltala 2007, 286-301.) Myös opistossa vaihdettavaan työvoimaan liittyvät epävarmuustekijät niveltyvät toistuvien resurssivähennysten ja voimakkaan kysyntälähtöisen toimintatavan myötä epävarmuuteen työn määrästä ja jatkuvuudesta. 
"Me olemme tavallaan heittopusseja kaikki tuntiopettajat koko ajan, että me olemme ihan kysynnän ja tarjonnan lain alla. \{...\}silloin enemmän sai opettaja toteuttaa itse itseään ja olla semmoinen kuin on ja sitten kurssit joko veti tai ei." Ulla, työkokemus 30 vuotta

"Minusta nykyään on aika paljon, mitä nyt tässä olen huomannut, niin nuo tuntiopettajat joutuvat hirveästi ottamaan yhteyksiä ihmisiin ja haalimaan mukaan, että saisivat ryhmiä, että saisivat sitä tuntipalkkiota...palkkaa sitten niistä töistä.” Leena, työkokemus 29 vuotta

Epävarmuus työn määrästä ja tulevaisuudesta tuo tuntiopettajille tulospaineita, jotka näyttäytyvät käytännössä aiempaa voimakkaampana huolena osallistujamäärien riittävyydestä, kurssien kannattavuudesta ja uusien kurssien perustamismahdollisuuksista. Kaikki tuntiopettajat eivät kuitenkaan näytä kohtaavan jatkuvaa epävarmuutta. Menestyville, kysytyille ainealueille riittää osallistujia, minkä vuoksi uusien kurssien perustaminen on helppoa.

"On niin suosittua, että kaikki uusi menee läpi, otetaan ilolla vastaan." Ritva, työkokemus 7 vuotta

Vaikka epävarmuus ei koettele kaikkia yhtä suuresti, näyttää se leimaavan laaja-alaisesti opiston henkilökunnan työtä, sillä myös vakinainen henkilökunta joutuu kamppailemaan vähäisten resurssien jakamiseen nivoutuvan epävarmuuden kanssa.

Rajallisten resurssien suuntaaminen opiston sisällä tuloksellisuuden perusteella voi synnyttää epävarmuuden ohella kilpailuhenkisyyttä ainealueiden ja niitä edustavien suunnittelijaopettajien välille, mikä koettelee opiston sisäistä yhteistyötä.

"\{...\}lähinnä nyt suunnittelijaopettajat ovat niitä, jotka tavallaan enemmän "tappelevat" siitä omasta reviiristään, että heillä on kaikki ne, mitä nyt on mahdollista saada niitä etuja sinne, jos semmoisia nyt on tarjolla." Pekka, työkokemus 30 vuotta

Vähäisten resurssien suuntaaminen toiminnan menestyksellisyyden perusteella näyttää tuoneen tulosvastuun ajatuksia opiston henkilökunnan työhön (vrt. Jokinen 2002, 48, 56). Tuntiopettajien on toimittava aiempaa tulosvastuullisemmin, jotta opettavien kurssien ja ansioiden määrä säilyisi ennallaan, mutta toisaalta myös suunnittelijaopettajien sekä päätoimisten opettajien on pyrittävä turvaamaan asemansa ja oman ainealueensa resurssit tuloksellisuuden kautta.

Suorituskeskeisyyden heijastuminen opistotyöhön ilmenee opiston henkilökunnan kokemusten valossa opisto-opettajan roolin muuttumisena. Opetustyötä tekevästä opettajasta on tullut suunnittelu- ja hallintotyötä tekevä, ainealueensa suorituskykyisyyttä kehittävä sopeutuja, jonka on mukauduttava toistuviin tehokkuuspaineisiin ja epävarmuuden sekä ristiriitojen ilmapiiriin (vrt. Ball 2001; 2003). Opiston opetushenkilökunnan työ näyttää siten muuttuneen aiempaa kuormittavammaksi ja haasteellisemmaksi.

Taloudellisen ajattelun ja suorituskyvykkyyden korostumisen myötä myös rehtorin rooli opistossa on muuttunut. Käytännön opistotyötä tekevästä puurtajasta on aineiston perusteella tullut alueellisessa opistossa aiempaa vahvemmin johtaja (vrt. Sihvonen 1996, 231), joka ohjaa opettajia tehokkuuteen ja suorituskyvykkyyteen $\mathrm{mm}$. resurssijaon kautta.

"\{...\}tietysti tuo huolenpito siitä, että nämä ihmiset, jotka ovat alaisina, että he jaksavat tehdä töitä ja se innostaminen siinä, että he tekisivät sen oman osuutensa sitten mahdollisimman hyvin ja silloin tietysti asiakkaatkin ovat tyytyväisiä. " Martti, työkokemus 30 vuotta

Markkinaperusteinen politiikka näyttää tuoneen monimuotoisia haasteita opiston henkilökunnan työhön vähentyneiden resurssien ja toistuvien tehostamistoimien seurauksena. Paineet oman ainealueen suorituskyvyn parantamiseen yhä voimakkaamman itsenäisen rahanhankinnan, kysynnän arvioinnin, trendien seuraamisen, toiminnan laadun tarkkailun ja kehittämisen kautta ovat nousseet opistotyön uusiksi, markkinaperusteista aikaa kehystäviksi haasteiksi, jotka koettelevat opiston sisäistä yhteistyötä sekä työnteon mielekkyyttä.

\section{Mitä opiston henkilökunnan kokemukset kertovat?}

Yhteiskuntateoriassa länsimaiden modernisaatiokehityksen ja globalisaation on nähty aiheuttavan 
jännitteitä ja polarisaatiota yksilöiden ja instituutioiden identiteeteille. Informaatioyhteiskunnan johtava teoreetikko Manuel Castells (1996, 1997) näkee nykyisen informaatioyhteiskunnan polarisaation perusjännitteenä vastakohdan instrumentaalisen vaihdon globaalien "verkostojen" ja paikallisten kulttuurien "identiteettien" välillä. Koulutuksen suhteen voi puhua jännitteestä kansallisen politiikan ja EU:n politiikan välillä.

Euroopan unionin koulutuspolitiikan painopisteenä on pyrkimys jäsenvaltioiden kilpailukyvyn ylläpitämiseen ja parantamiseen, tukemalla ja kehittämällä kansalaisten osaamista, tietoja, taitoja sekä kykyjä laadukkaan koulutuksen kautta (ks. Naumanen, Leppänen \& Rinne 2008, 277). Kansallisen tason sivistykselliset ihanteet ja perinteet ovat osin jääneet koulutuksen välineellisiä pyrkimyksiä ja tehokkuustavoitteita tukevien kansainvälisten vaikutteiden jalkoihin. Opiston käytännössä ilmenevät markkinaperusteisuuden piirteet, kuten markkinoille suuntautuminen, voimistunut kilpailu ja tulosvastuun, arvioinnin sekä taloudellisen ajattelun korostuminen kuvaavatkin osaltaan kansainvälisten vaikutteiden heijastumista paikalliselle tasolle (vrt. Vanttaja \& Rinne 2008b, 409410).

Jurgen Habermasin teoriassa polarisaatio muodostuu systeemin ja elämismaailman törmäämisestä, minkä seurauksena systeemi "kolonialisoi" kommunikatiivisen rationaalisuuden hallitsemaa elämismaailmaa. Käytännössä jännitteet aiheuttavat sen, että ihmisten keskinäiset suhteet sekä ihmisten ja instituutioiden väliset suhteet, kuten luottamus ja kunnioitus joutuvat kamppailemaan voimakentässä, jonka virittää liiketaloudellista tehokkuutta korostava kansainvälisen kilpailun ja hallinnon järjestelmä. (Niiniluoto 2003.) Julkinen hallinta, asiakaslähtöisyyden, arvioinnin, mittaamisen ja vertailun kulttuurien kautta, on muuttanut kansanlaisopistotoimintaa ja luonut jännitteitä henkilöstön ammatillisiin identiteetteihin.

Paljon työkokemusta omaavan kansalaisopiston henkilökunnan kokemuksissa polarisaatio vanhan "sivistysopiston" ja uuden "markkinaopiston" välillä on selvästi nähtävissä. Kansalaisopiston perinteiset roolit sivistyksellisen tasa-arvoisuuden edistäjänä ja yhteisön ohjaajana näyttävät murentuneen, kun opiston on toistuvien resurssileikkausten myötä täytynyt omaksua yritysmaailmalle ominaisia toimintatapoja, kulttuureja ja eettisiä piirteitä.

Kunnan voimistunut taloudellinen päätäntäval- ta näyttäytyy opistotoiminnan käytännön tasolla suorituskyvykkyyden parantamista tavoittelevana sääntelyn ja ohjauksen välineenä (vrt. Ball 2001, 28; 2003, 217; Lähdesmäki 2003, 232). Markkinaperiaatteet ovat opiston henkilökunnan kokemusten valossa muotoutuneet opistotoiminnan arkeen kunnan resurssijaon ja säästötoimien kautta. Kunnan opistolle myöntämät aiempaa vähäisemmät resurssit pakottavat opiston tehostamistoimiin ja markkinaperiaatteiden hyödyntämiseen, ylläpitääkseen toimintaansa.

Paikalliseen sivistystarpeeseen opintoja kohdentavasta opistotoiminnasta muotoutui lamavuosien aikana opintopalveluiden tarjoaja (Sihvonen 1996). Resurssien toistuvien leikkausten, opintomaksujen korotusten, kilpailun ja kysyntälähtöisyyden voimistumisen seurauksena opiston rooli näyttää 2000-luvulla muuttuneen opintojen tarjoajasta alueellisten opintopalveluiden myyjäksi. Toiminnan tarkoitusperät ovat samalla muuttuneet yhteiskunnallisista, hyvinvointivaltion tavoitteita edistävistä pyrkimyksistä kohti opistotoiminnan ylläpitämisen ja markkinoilla selviytymisen tavoitetta.

Opiston henkilökunnan kokemukset osoittavat osaltaan pohjoismaisen hyvinvointivaltion rakenteiden murentumista. Opistotoiminnan kohdalla pohjoismaisen hyvinvointivaltion yhteisvastuullisuuden periaatteista on siirrytty kohti yksilökeskeistä, liberaalia hyvinvointia, jossa jokainen instituutio ja yksilö ovat vastuussa omasta menestymisestään. Liberaalin hyvinvointivaltiomallin ajatusten tunkeutuminen osaksi koulutuspolitiikkaamme heijastelee siirtymää hyvinvointivaltiosta kilpailuvaltion suuntaan (vrt. Heiskala \& Luhtakallio 2006, 10-11).

Opetustyön vähentyminen (vrt. Jokinen 2002, 265), yritysmäisen johtajuuden (vrt. Sihvonen 1996) ja tulosvastuullisuuden esiinmarssi ovat tuoneet epävarmuutta ja ristiriitaisuuden ilmapiiriä henkilökunnan työhön. Opettajien kokemusten valossa opiston ainealueet ovat eriarvoistuneet. Opistossa on menestyvien, kysyttyjen ja kehittämiskykyisten ainealueiden rinnalla heikosti menestyviä aineita, joiden toiminnan edellytyksiä on toistuvasti karsittu muita voimakkaammin.

Menestyminen näyttäytyy opistossa markkinaperusteisuuden aikana keskeisenä opettajan ja toiminnan arvon määrittäjänä (vrt. Ball 2001;2003), ohjaten opettajien käsityksiä itsestään, osaamisestaan ja ammatillisesta identiteetistään. Markkinaperusteisuuden aika näyttää tehneen opiston hen- 
kilökunnasta aktiivisia sopeutujia, jotka ovat vastuussa omasta menestymisestään ja joiden ammatillisten identiteettien rakentuminen on jatkuvassa muokkaantumisen tilassa. Selkeiden ja läpi elämän jatkuvien ammatillisten identiteettien aika vaikuttaa opistotoiminnan osalta olevan ohi (vrt. Filander 2007).

Markkinaperusteisen ajan kilpailullista opistotoimintaa, opiston roolin ja sen henkilökunnan ammatillisten identiteettien muutosta voisi aineiston havaintojen pohjalta kuvata arkikielen termein pelkistetysti ja leikillisesti formulasanastolla. Opiston rehtori on tallipäällikkö, kun taas suunnittelijaopettajat näyttäytyvät aineiston valossa kilpailijan rooleissa ja tuntiopettajat "menopelin" testaajina.

Tallin ja kilpailijoiden tulee saada sponsoreita, olla tehokkaita ja osoittaa tuloksellisuutensa. Kun sivistyksen keidas tarjoaa asiakkaille ja henkilökunnalle mahdollisuuden luovaan lepoon sekä kriittisen pohtivaan opetukseen ja oppimiseen, kiteytyy formulatallin toiminnan idea kattojärjestöltä tulevien sääntöjen puitteissa toteutuvaan kilpailuun. Sivistyksen ja oppimisen päämääristä on siirrytty kilpailun ihannointiin, jossa liiketoiminnan idea ja oman edun tavoittelu asetetaan muiden päämäärien yläpuolelle.

\section{Kansalaisopistotoiminta tulevaisuudessa}

Alueellisesti laajan ja harvaan asutun Suomen kansalaisopistotoiminnan tulevaisuuden suunnan voi katsoa olevan kiinteästi sidoksissa toiminnan saaman julkisen rahoituksen määrään. Talouskriisi ja valtion tuottavuusohjelmien läpivieminen kiristävät entisestään kuntien tiukkaa taloustilannetta, mikä enteilee opistotoimintaan kohdistettavan julkisen tuen määrän supistumista. Tällöin opistojen olisi hankittava yhä enemmän rahoitusta itsenäisesti ja ohjattava toimintaansa markkinoiden vaatimusten perusteella, ylläpitääkseen toimintaansa. Markkinaperiaatteiden voimistuminen voisi pahimmillaan etäännyttää opistotoiminnan lopullisesti sen perinteisistä, hyvinvointivaltion tavoitteita tukevista tehtävistä. Onkin syytä kysyä voiko opistotoiminta säilyttää asemansa julkisesti tuettuna palveluna, jos sen perinteiset roolit rapautuvat täysin (vrt. Toiviainen 2002, 29)?

Tulevaisuudessa opistotoiminnan pääasiallinen rahoitus muodostuu näillä näkymin edelleen laskennallisesti jaettavasta perusrahoituksesta. Tä- män rinnalle on tulossa laatu- ja kehittämisrahoitus, jonka tarkoituksena on tukea opistotoiminnan laadun kehittämistä ja toiminnan keskeisten tavoitteiden toteutumista toteutumista (OPM 2009). Tällä rahoitusjärjestelmän muutoksella pyritään turvaamaan opintojen saatavuus ja sivistyksellisen tasa-arvon toteutuminen, mutta muutos voi myös edesauttaa markkinaperusteista kehityssuuntaa. Toiminnan laatuun ja kehittämiseen perustuva palkitseva lisärahoitus voi osaltaan tukea opiston sisäistä kilpailuhenkisyyttä, kannustamalla opiston henkilökuntaa entistä voimakkaammin oman suorituskyvykkyyden ja tuloksellisuuden parantamiseen toiminnan kehittämisen kautta.

Lisäksi markkinaperusteista kehityssuuntaa voi tukea EU:n harjoittama politiikka, joka näyttää myös tulevaisuudessa ohjaavan kansallista politiikkaa yhä vahvemmin työelämälähtöisten vaatimusten ja kilpailukyvyn parantamisen suuntaan (ks. Eurooppa 2020). Oman painoarvonsa tulevaan aikuiskoulutuspolitiikkaan luovat toisaal ta yhteiskunnalliset muutokset, kuten väestön ikääntyminen, työelämän muutokset, maahanmuuttajien määrän kasvu ja pyrkimykset ikäluokkien välisten koulutuserojen tasaamiseen (ks. Vanttaja \& Rinne 2008a, 109 - 110). Voisiko kansalaisopistotoiminta oikeuttaa asemansa näiden yhteiskunnallisten muutosten kehyksessä, ja vastata siten välineellisen politiikan vaatimuksiin?

Markkinaperusteisuuteen liittyviä tehostamistoimia ei tule ymmärtää yksiselitteisesti kielteisenä ilmiönä, mutta ne näyttävät tuoneen opistotoimintaan monia perustavanlaatuisia muutoksia. Tehostamistoimien myötä heikentynyt sivistyksellinen tasa-arvoisuus heijastelee yhteiskunnan kahtiajakautumista ja oikeudenmukaisuuden kaventumista. On siis aiheellista kysyä miten paljon tehokkuus- ja kilpailueetoksen hyvinvointiyhteiskunnallamme on varaa lisätä tehokkuutta oikeudenmukaisuuden kustannuksella? Opistotoiminnan osalta ajankohtaiseksi kysymykseksi nousee se, onko mahdollista saavuttaa tasapaino toiminnan tehokkuuden ja sosiaaliseen oikeudenmukaisuuden välillä?

\section{Viitteet}

1. Tehostamistoimien kautta voidaan pyrkiä toiminnan kustannustehokkuuteen, jolla tarkoitetaan kustannusten mahdollisimman suurta kaventamista suhteessa haluttuun tuotostasoon. Kustannus- 
tehokkuutta laajemmassa merkityksessä, tehokkuuden voi ymmärtää kokonaistehokkuutena, jolloin asiat pyritään tekemään parhaalla mahdollisella tavalla. Tämä voi merkitä esimerkiksi työolojen ja-viihtyvyyden parantamista tai asiakkaiden tyytyväisyyden tavoittelua. Kokonaistehokkuuden saavuttaminen voi edellyttää kustannustehokasta toimintatapaa. (Kanniainen 2002, 18-19.) Koulutuksen osalta tehokkuustavoitteisuus on ilmennyt markkinaperusteisuuden aikana käytännössä pyrkimyksinä kustannustehokkaaseen toimintatapaan parantamalla toiminnan kokonaistehokkuutta (ks. Alanen 1992,14-15).

2. Tarkastelun kohteena olevaa opistoa ja haastateltavien oikeita nimiä ei tuoda esille haastateltavien anonymiteetin suojaamiseksi.

3. Haastatteluteemojen rakentamisessa hyödynnettiin Juha Sihvosen (1996) väitöskirjaa. Myös muiden markkinaperusteista politiikkaa ja koulutusta käsittelevien tutkimusten antia hyödynnettiin, sillä vapaaseen sivistystyöhön ja siihen nivoutuvaan markkinaperusteiseen toimintatapaan liittyviä aiempia tutkimuksia on vähän.

\section{Lähteet}

Alanen, A. (1988). Suomen aikuiskasvatuksen hallinto ja organisaatiot. Tampereen yliopisto.

Alanen, A. (1992). Suomen aikuiskasvatuksen organisaatiomuodot. Tampereen yliopisto.

Antikainen, A. (2006). In search of the Nordic model in education. Scandinavian journal of educational research 50(3), 229-243.

Ball, S.J. (2001). Globaalit toimintaperiaatteet ja kansalliset politiikat eurooppalaisessa koulutuksessa. Teoksessa Jauhiainen, A., Rinne, R. \& Tähtinen, J. (toim.) Koulutuspolitiikka Suomessa ja ylikansalliset mallit. Suomen kasvatustieteellinen seura. Turku: Painosalama, 21-43.

Ball, S.J. (2003). The teacher's soul and the terrors of performativity. Journal of education policy 18(2), 215-228.

Ball, S.J. (2007). Education plc. Understanding private sector participation in public sector education. Abingdon: Routledge.

Castells, M. (1996). The rise of the network so- ciety. The information age: economy, society and culture, volume 1. Cambridge: Blackwell.

Castells, M. (1997). The power of identity, volume 2. Oxford: Blackwell.

Eurooppa (2020). Alykkään, kestävän ja osallistuvan kasvun strategia. Euroopan komission tiedonanto.

Filander, K. (2007). Deconstructing dominant discourses on vocational education. In Rinne, R., Heikkinen, A. \& Salo, P. (eds) Adult education - liberty, fraternity, equality? Nordig views on lifelong learning. Research in educational siences 28. Helsinki: Finnish educational research association, 261-274.

Heiskala, R. \& Luhtakallio, R. (2006). Uusi jako. Miten Suomesta tuli kilpailukyky-yhteiskunta? Helsinki: Gaudeamus.

Jarvis, P. (1996). Oppimisen markkinat. Aikuiskasvatus 16(1), 12-18.

Jokinen, J. (2002). Aikuisopettajan identiteetti. Yksinäisestä sankariopettajasta tiimiytyneeseen yrittäjään? Kasvatustieteen akateeminen väitöskirja. Tampereen yliopisto.

Kanniainen, V. (2002). Puhtia hyvinvointiyhteiskunnan purjeisiin. Peruspalveluja uudella tavalla. Elinkeinoelämän valtuuskunta. Helsinki: Taloustieto.

Kantola, A. (2006). Markkinakuri ja managerivalta. Poliittinen hallinta Suomen 1990-luvun talouskriisissä. Helsinki: Loki-kirjat.

Lähdesmäki, K. (2003). New public management ja julkisen sektorin uudistaminen. Tutkimus tehokkuusperiaatteista, julkisesta yrittäjyydestä ja tulosvastuusta sekä niiden määrittelemisestä valtion keskushallinnon reformeista Suomessa 1980-luvun lopulta 2000-luvun alkuun. Hallintotieteen akateeminen väitöskirja. Vasaan yliopisto.

Naumanen, P., Leppänen, R. \& Rinne, R. (2008). Euroopan unionin muuttuva koulutuspolitiikka. Teoksessa Rinne, R., Jõgi, L., Leppänen, R., Korppas, M. \& Klemelä K. (toim.) Suomalainen ja virolainen koulutus ja EU:n uusi koulutuspolitiikka. Turun yliopiston kasvatustieteiden laitos, 227-326.

Niiniluoto, I. (2003). Dynaaminen sivistysyliopisto. Rehtorin avajaispuhe 10.9.2003. http:// yliopistolehti.helsinki.fi/2003_12/ avajaispuhe.html 
OPM. (2009). Vapaan sivistystyön kehittämisohjelma 2009-2012. Opetusministeriön asettaman valmisteluryhmän loppuraportti. http:// www.minedu.fi/OPM/Julkaisut/2009/ Vapaan_sivistystyon_kehittamisohjelma.html

Rinne, R., Kivirauma, J. \& Simola, H. (2002).

Shoots of revisionist education policy or just slow readjustment? The Finnish case of educational reconstruction. Journal of education policy 17(6), 643-658.

Rinne, R. \& Vanttaja, M. (1999). Suomalaista aikuiskoulutuspolitiikkaa: muutoksia ja jännitteitä 1980- ja 1990-luvuilla. Aikuiskoulutusneuvosto ja Turun yliopiston kasvatustieteiden laitos. Opetusministeriö.

Sihvonen, J. (1989). Murtuvatko opistotyön "myytit"? Teoksessa. Oksanen, A., Kauppi, A., Laurila, A., Toiviainen, T. \& Tuomisto, J. (toim.) Kriittinen ajattelu aikuiskasvatukses$s a$. Kansanvalistusseura ja Aikuiskasvatuksen tutkimusseura. Helsinki: Kirjastopalvelu, 65-74.

Sihvonen, J. (1996). Sivistystä kaikille vai valituille? Kansalaisopistotoiminnan kehitys vapaasta kansanvalistustyöstä maksupalveluun. Aikuiskasvatustieteen akateeminen väitöskirja. Tampereen yliopisto.

Sihvonen, J. (2004). Suomalaisia näkökulmia eurooppalaiseen vapaaseen sivistystyöhön. Teoksessa Niemelä, S. \& Luutonen, M. (toim.) Taitava ihminen - toimiva kansalainen. Aikuisopiskelun motiiveja ja merkityksiä. Vapaan sivistystyön yhteisjärjestö ja Kansanvalistusseura. Vantaa: Dark Oy, 115-124.

Siltala, J. (2007). Työelämän huonontumisen lyhyt historia. Muutokset hyvinvointivaltioi- den ajasta globaaliin hyperkilpailuun. Helsinki: Otava.

Toiviainen, T. (2002). Vapaan sivistystyön visiot. Castrènilaista laatuviiniä uusissa tammitynnyreissä. Helsingin kaupungin suomenkielinen työväenopisto.

Tuomisto, J. (1998). Keskitetystä aikuiskoulutussuunnittelusta markkinoiden ohjaukseen ja takaisin. Aikuiskasvatus 18(4), 268-280.

Tuomola-Karp, P. (2005). Laatu luottamuksen rakentamisena - laatukäsitys kansanopistossa. Valtiotieteen akateeminen väitöskirja. Helsingin yliopisto.

Vaherva, T., Malinen, A., Moisio, A., Raivola, R. Salo, P., Kantasalmi, K., Kamppi, P. \& Silvennoinen, H. (2006). Vapaan sivistystyön oppilaitosrakenne ja palvelukyky. Koulutuksen arviointineuvoston julkaisuja. Jyväskylä.

Vanttaja, M. \& Rinne, R. (2008a). Suomalainen koulutusjärjestelmä ja koulutuspolitiikka 1990ja 2000-luvuilla. Teoksessa Rinne, R., Jõgi, L., Leppänen, R., Korppas, M. \& Klemelä K. (toim.) Suomalainen ja virolainen koulutus ja EU:n uusi koulutuspolitiikka. Turun yliopiston kasvatustieteiden laitos, $19-128$.

Vanttaja, M. \& Rinne, R. (2008b). Suomen ja Viron kouluvertailu ja Euroopan unionin merkitys. Teoksessa Rinne, R., Jõgi, L., Leppänen, R., Korppas, M. \& Klemelä K. (toim.) Suomalainen ja virolainen koulutus ja EU:n uusi koulutuspolitiikka. Turun yliopiston kasvatustieteiden laitos, $395-413$.

Yrjölä, P. (toim.) (1996). Kansalaisopiston tila 1995. Opetushallitus.

Artikkeli saapui toimitukseen 2.9.2010. Se hyväksyttiin julkaistavaksi toimituskunnan kokouksessa 10.5.2010.

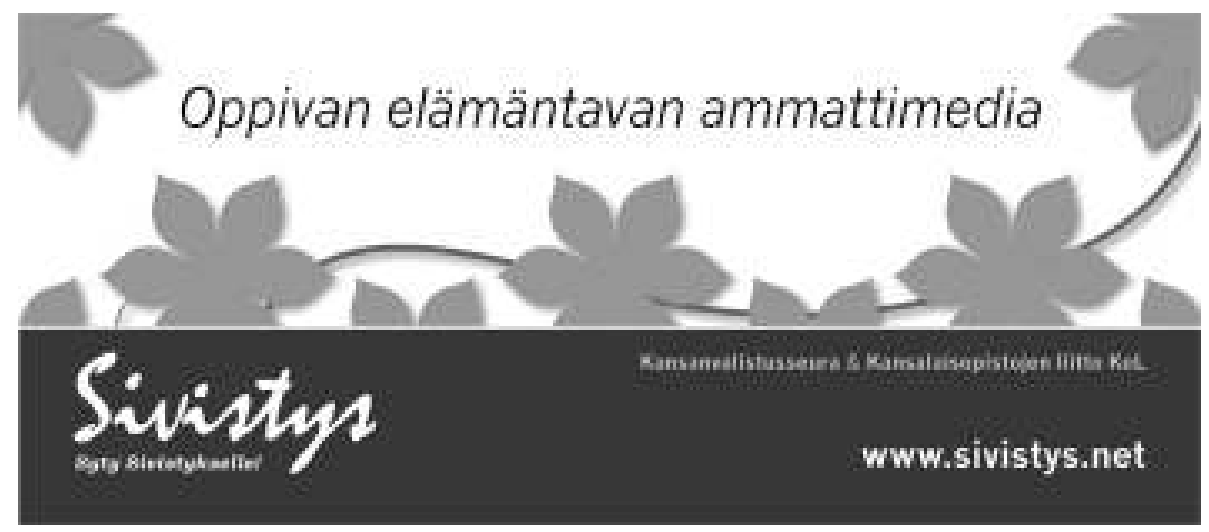

